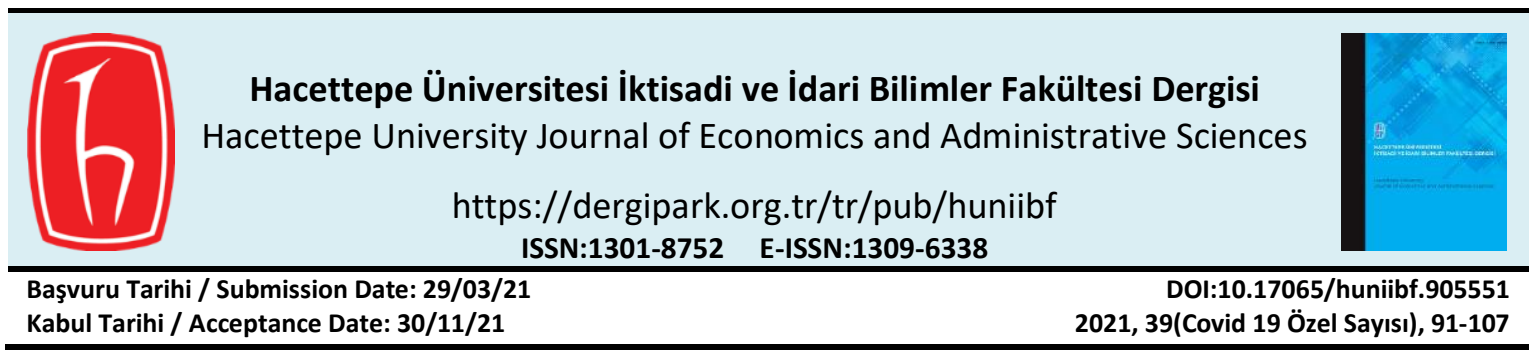

Araştırma Makalesi / Research Article

\title{
Türkiye'de Gıda Perakendeciliğinde Dijitalleşme ve COVID-19'un Dijitalleşme Üzerindeki Etkilerini Belirlemeye Yönelik Nitel Bir Araştırma
}

Ferhan Gezici ${ }^{1}$, Dilay Çelebi Gonidis², İsra Hatipoğlu ${ }^{3}$, Dilşad Evci ${ }^{4}$, Fatma Selçuk ${ }^{5}$

Öz

COVID-19 pandemisi sırasında çevrimiçi hizmetlere olan talepteki artış; pandemi sonrası bir dünyada da perakende sektöründe çevrimiçi alışveriş sisteminin daha fazla ilgi göreceğine işaret etmektedir. Bu makale, dijitalleşme ile e-ticaretin yükselişine ve bu değişimin gıda perakende sektöründeki etkilerinin COVID-19 pandemisi ile hızlanmasına ilişkin tartışmalara katkı sunmayı amaçlamaktadır. Bu amaçla, pandemi öncesinde de gündemde olan çevrimiçi alışverişin, pandemi sürecinde nasıl bir artış gösterdiği ve işletmelerin ne tür aksiyonlar aldığı sorularına cevap aranacaktır. Araştırma amacına uygun olarak, üç farklı kategorideki organize gıda perakende işletmeleri, Türkiye'nin en büyük metropol kenti olan İstanbul'dan seçilen örneklem ile derinlemesine görüşmelere dayalı olarak analiz edilmiştir. Araştırmanın öne çıkan bulguları, çevrimiçi alışverişe yönelen tüketici taleplerini pandeminin hızlandırdığı yönündedir. Ancak, pandeminin ilk dönemlerinde yaşanan çevrimiçi alışveriş talebinin artışı, normalleşme ile birlikte etkisini bir ölçüde kaybetmiştir. Dijital altyapısını önceden geliştirmiş olan işletmeler çevrimiçi alışveriş taleplerine daha kolay cevap verirken, sermayesi kısıtı yerel marketlerin büyük bir bölümü ise çevrimiçi altyapıya yatıım yapmayı gerekli görmemiştir. Gıda perakendede diğer perakende sektörlerine göre çevrimiçi alışverişin payının çok yükselmeyeceği ve sektörün geleceğinde hem fiziksel hem de sanal mağazacılı̆ıın yer alacağı anlaşılmaktadır. Yine de çevrimiçi satışların artması, gıda perakende işletmelerinin kent içindeki mekânsal intiyaçlarını değiştirecektir.

Anahtar Kelimeler: COVID-19, gıda perakende, e-ticaret, İstanbul.

\section{A Qualitative Study to Determine Digitization in Food Retailing in Turkey and the Effects of COVID-19 on Digitization}

\begin{abstract}
Increase in demand for online services during the COVID-19 pandemic indicates that the online shopping system will attract more attention in the retail sector in a post-pandemic world. This article aims to contribute to the discussions about the online shopping and the changes on the food retail sector with the COVID-19 pandemic. For this purpose, this article has given answers to the question of how online shopping has increased and what kind of actions businesses took during the pandemic process. According to the research objectives, organized food retail businesses in three different categories selected from Istanbul were taken as a sample and analyzed based on in-depth interviews. The significant findings of the research support the idea that the consumer demands for online shopping has been accelerated by the COVID-19 pandemic. However, the increase in online shopping demand in the early stages of the pandemic lost its effect to some extent with the normalization. While businesses that have previously developed their digital infrastructure can more easily respond to on-line shopping demands, most of the local markets with limited capital did not consider to invest in online infrastructure. It is understood that the online shopping in food retail will not increase much, when compared to other retail sectors. As a result, both physical and online shopping will take place in the future of the food retail sector. Nevertheless, increasing online sales will change the spatial needs of food retail businesses within the city.
\end{abstract}

Keywords: COVID-19, food retail, e-commerce, Istanbul.

1 Sorumlu Yazar (Corresponding Author), Prof.Dr., İstanbul Teknik Üniversitesi, Şehir ve Bölge Planlama Bölümü, gezicif@itu.edu.tr, https://orcid.org/0000-0001-5178-4982

2 Prof. Dr, İstanbul Teknik Üniversitesi, İ̧sletme Mühendisliği Bölümü, celebid@itu.edu.tr, https://orcid.org/0000-0002-7103-3868

${ }^{3}$ Araştırma Görevlisi, İstanbul Teknik Üniversitesi, Şehir ve Bölge Planlama Bölümü, israhatipoglu@gmail.com, https://orcid.org/0000-0002-6587-9795

${ }^{4}$ Doktora Öğrencisi, İstanbul Teknik Üniversitesi, İşletme Bölümü, dcelebi@gmail.com, https://orcid.org/0000-0001-5852-1069

5 Yüksek Lisans Öğrencisi, İstanbul Teknik Üniversitesi, Şehir ve Bölge Planlama Anabilim Dalı, Bölge Planlama Programı, fselcuk32@gmail.com, https://orcid.org/0000-0001-9564-7998 


\section{GiRiş}

Aralık 2019'da Çin'de başlayan COVID-19 pandemisinin şok etkisi ve salgını durdurmak için alınan önlemler, ülke ekonomilerinin kiminde durgunluk, kiminde ise küçülmeye sebep olan ve devam eden büyük bir küresel ekonomik kriz yaratmıştır. Dünyada hızla üretilen raporlar, en fazla etkilenen ve etkilenmesi muhtemel sektörleri konaklama-yiyecek hizmetleri, perakende-toptan ticaret, sanayi, gayrimenkul ve idari hizmetler olarak belirlemiştir (International Labor Organization [ILO], 2020; Stephany, Stoehr, Darius, Neuhäuser, Teutloff ve Braesemann, 2020). Ülkeler belirli düzeyde üretime devam etme yönünde tedbirlerini geliştirirken, seyahatlerin sınırlanması, daha da ötesi ülke kapılarının kapanması, perakende sektörünün önemli bir kısmının, restoran ve eğlence yerlerinin sosyal mesafe kuralı gereği kapanması büyük bir arz şoku olarak ortaya çıkmıştır. Buna karşın, sağlık sektörü ve gıda perakende talebin en yüksek olduğu sektörler olarak öne çıkmaktadır (Önemli, 2020; Jones, 2020). Oldukça kısa sürede yaşanan tüm bu değişimler, kent yaşamı ve ekonomisi üzerinde önemli etkiler yaratmaktadır.

Günümüzde gıda üretimi, gelişmiş ve gelişmekte olan ülkelerde ortalama olarak GSYiH'nin \%12'sini oluşturan canlı bir sektör durumundadır (Bakalis, Valdramidis, Argyropoulos, Ahrne, Chen, Cullen, Cummins, Datta, Emmanouilidis, Foster, Fryer, Gouseti, Hospido, Knoerzer, LeBail, Marangoni, Pingfan, Schlüter, Taoukis, Xanthakis ve Van Impe, 2020). Perakende sektörünün diğer alanlarına göre gıda perakende sektörünün, COVID-19 pandemisinden daha az etkilendiği, karantina döneminde dahi faaliyetlerine devam ettikleri bilinmektedir. Nielsen Perakende Endeksi verilerine göre pandeminin ilk yarısında gıda dışı perakende \%34 düşüş yaşarken, gıda perakendenin \%33 büyüdüğü görülmektedir (Anonim, 2020a). Öte yandan, pandemi öncesinde de farkındalığın arttığı gıda güvenliği ve sağlıklı gıdaya erişimin önemi, pandemi ile daha da görünür bir hal almıştır. Bu doğrultuda, esasen talebin düşmediği, ama yeni koşullar karşısında zorluklarla karşılaşan gıda perakende sektörünün analiz edilmesi, sorunlarının tespit edilmesi ve geleceğe yönelik olası aksiyonların planlanması kritik öneme sahiptir.

Türkiye'de de karantina ve “Evde Kal” uygulamaları (T.C. İçişleri Bakanlığı, 2020a), zorunlu olmayan işletme faaliyetlerinin kısıtlanması veya kapanma kararları (T.C. İçişleri Bakanlığı, 2020b) ve bireylerin tüketim davranışlarındaki değişiklikler perakende sektörünün krize adapte olabilmesi için yeni stratejiler geliştirmesini zorunlu kılmıştır. NACE Rev 2'li kodlara göre ilgili sektörün istihdam ve işletme sayısı açısından Türkiye'de (istihdamın $\% 9,27$ 'si) ve bu çalışmanın yürütüldüğü İstanbul'da (istihdamın \%9,15'i, işletmelerin \%14,45'i) en yüksek paya sahip olduğu bilinmektedir (Sosyal Güvenlik Kurumu [SGK], 2018). Gıda perakende sektörünün gıda dışı perakendeye göre, COVID-19 pandemisinden negatif yönde daha az etkilendiği düşünülmekle birlikte, gıda endüstrisinin savunmasız ve kırılgan bir yapıda olduğu unutulmamalıdır (Anonim, 2020b; Teodoro, 2020).

COVID-19 pandemisinin hem arz hem talep yönüyle yarattığı şok, gıda perakende sektöründe de üretim ve tedarikle ilişkili olarak arzı yönetebilme ve müşteriye yönelik olarak da talebi karşılayabilme konusunda kritik önemdedir. Örneğin, pandemi sırasında çevrimiçi hizmetlere olan talepteki artış; pandemi sonrası bir dünyada da gıda perakende sektöründe çevrimiçi alışveriş sisteminin daha fazla ilgi göreceğine işaret etmektedir (Hobbs, 2020). Bu değişime kısa vadede çevrimiçi hizmet sunulması bir çözüm gibi görünürken, uzun vadede ise belirli mağazaların kapatılarak, depolar üzerinden mikro dağıtım yapılması bir cevap olabilir.

Bu makale, dijitalleşme ile e-ticaretin yükselişini ve bu değişimin gıda perakende sektöründeki etkilerinin, COVID-19 pandemisi ile hızlanmasına ilişkin tartışmalara katkı sunmayı amaçlamaktadır. Bu amaçla, pandemi öncesinde de gündemde olan çevrimiçi alışverişin, pandemi sürecinde nasıl artış gösterdiği ve işletmelerin aksiyonlarını nasıl etkilediği sorularına cevap aranacaktır. Türkiye'de de COViD19 ve gıda ile ilişkili çalışmalar (Akbudak ve Özgür, 2021; Akkan ve Bozkurt, 2020; Alanlar, 2021; Hatipoğlu, 2021; Şen, 2020) olmakla birlikte, bilgimiz dahilinde pandeminin gıda perakende sektörüne doğrudan etkilerine ilişkin çalışma yoktur. Hacıalioğlu ve Sağlam (2021), İri (2021), Güven (2020) Kocaman, Kocaman ve Teyin (2021)'nin çalışmaları, Covid-19 pandemisinin tüketici tercihlerini değiştirdiği ve çevrimiçine yönelmenin arttığını ortaya koymuştur. Dolayısıyla, bu eğilime sektörün nasıl tepki vereceği kritik olmakta ve bu makaleye konu araştırmanın gerekliliğini desteklemektedir. Bir sonraki bölümde, e-ticaretin 
yükselişi ve perakende sektöründeki etkilerine ilişkin bir literatür değerlendirmesi yapılmış, araştırmanın yönteminin açıklanmasııın ardından, İstanbul'da konumlanmış 22 gıda perakende işletmesi ile yapılan derinlemesine görüşmelere dayalı olarak araştırma bulguları sunulmuştur.

\section{PERAKENDE VE GIDA PERAKENDE SEKTÖRÜNDE DIJITALLEŞME}

\subsection{E-ticaretin Yükselişi ve COVID-19 Pandemisinin Perakende Sektörüne Etkileri}

21. y.y. dijitalleşme ile hem dünya ekonomisinde hem de günlük yaşamda hızlı ve kritik değişimlere neden olmaktadır. Teknoloji şirketleri, bugün pek çok ülkenin ulusal gelirini aşan gelirleri ile dünyaya egemen olurken, bir yandan da sürekli değişen ve gelişen yeni teknolojiler-sürümler ile tüketimi teşvik etmektedir. Teknolojinin, ekonomik büyüme ve verimlilik üzerindeki etkileri çoğunlukla ekonomistler tarafından olumlu görülmekle birlikte, Acemoğlu (2018)'nun yaklaşımı, konunun bu kadar basit olmadığına vurgu yapmaktadır. Acemoğlu (2018)'na göre çalışanların, daha önce yaptıkları işlerde verimlerini artıracak "kolaylaştıııı teknolojiler", maaşları ve işgücü talebini de arttırmaktadır. Ancak çok amaçlı, yeniden programlanabilir robotların otomotiv montaj hatlarında kullanılması gibi sıradanlaşan "ikame teknolojiler" ise çalışanların işlerini elinden almakta ve bu durum, maaşları düşürüp, insanları işsiz bırakmaktadır (Bloomberg, 2018).

Teknolojinin, bir kent veya bölge ekonomisi üzerindeki etkileri tartışılırken, ekonomik büyüme, verimlilik ve istihdama yönelik etkiler ele alınmaktadır. Öte yandan dijitalleşme, teknolojinin sağladığı altyapı ile ekonomiyi etkilediği gibi, insanların gündelik hayatında pek çok şeyin hızlıca değiştiği kolaylaştırıcı bir rol de oynamaktadır. Kamu kurumları ile olan ilişkiler e-devlet üzerinden, bankacılık işlemleri e-bankacılık olarak, seyahat rezervasyonları çevrimiçi yapılabilirken, bazı iş kollarının alanı daralmakta veya ortadan kalkmaktadır. Benzer şekilde, e-ticaretteki artı̧ özellikle genç nüfus, eğitim düzeyi ve teknoloji okuryazarlı̆ının daha yüksek olduğu ülke ve kentlerde dikkati çekmektedir. Pandemi öncesinde de küresel e-ticaret hacmindeki artış (Şekil 1), perakende sektöründe ve ekonomik faaliyetlerin gerçekleştiği kentlerde yeni organizasyonlar ve mekânsal ihtiyaçları ortaya çıkarmaktadır.

\section{Şekil 1: Küresel E-Ticaret Hacminin Değişimi (milyar dolar)}

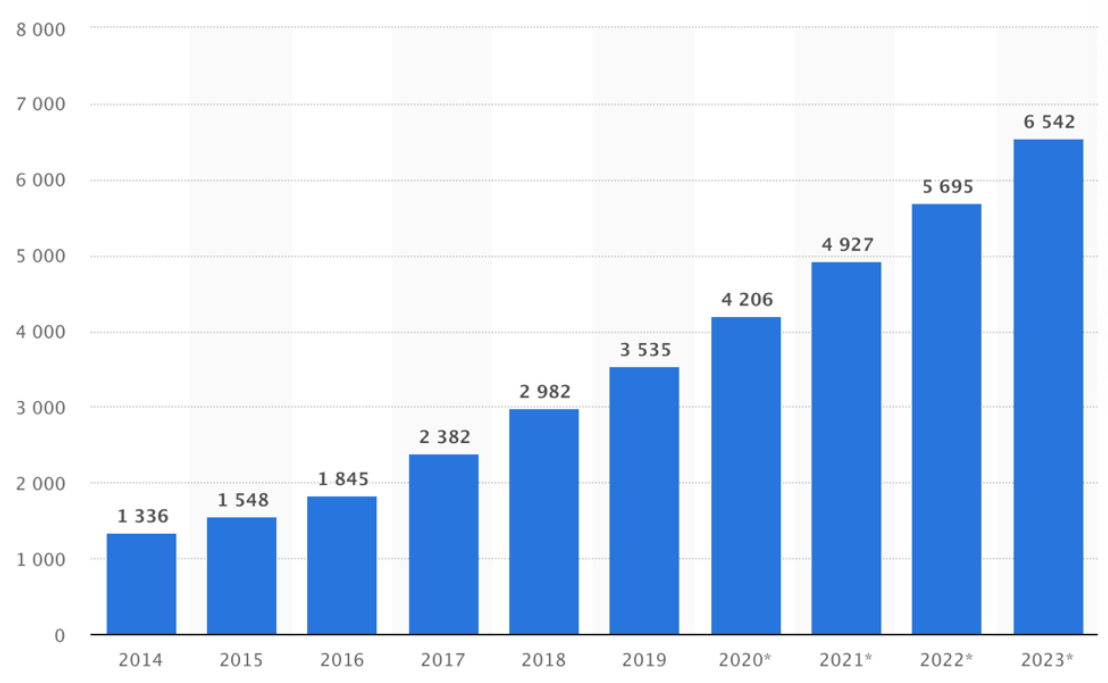

* Belirtilen yılların verisi tahminidir.

Kaynak: Anonim (2020c)

E-ticaretin ilk zamanlarında, çevrimiçi satış mağazaları da geleneksel ticarette olduğu gibi ürünleri toptan alıp, belirli bir kâr marjı ile tüketicilere satmaktadır. Amazon ${ }^{1}$ ve ardından Alibaba dramatik şekilde yenilikçi iş modelini uygulamaya geçirmiş ve platformlarını üçüncü şahıs tüccarlara açmıştır. Bu modelde, 
bir sanal pazar alanı olarak hizmet sunan platformlar hiçbir ürünü satın almadan yalnızca satılan üründen işlem ücreti almaktadır. Bu platformları kullanan, özellikle küçük ve orta boy işletmelerin avantajları ise, daha yaygın bir pazara ulaşmak için görünürlüklerini arttırmak ve küresel lojistik sistemine erişmek olarak belirtilmektedir. Özellikle bu model uygulamalarının, kitap ve CD gibi, müşterinin görerek, dokunarak almasının görece gerekmediği, daha az sürprizli ürünlerle başladığı da bilinmektedir (Moriset, 2020). Çevrimiçi alışverişin, tüketiciler için en büyük avantajı ise, ürünün maliyeti ve çeşitliliğini göz önüne alarak her zaman, her yerde, her şeyi satın alabilecek olmasıdır. Öte yandan, Amazon'un, bir müşterinin satın aldıklarını analiz eden ve benzer satın alma geçmişine sahip kişilerin satın aldığı diğer ürünleri öneren filtreleme teknolojisini kullanması da tüketicinin takibe alınmasını getirmiştir (Mellahi ve Johnson, 2000). Genel olarak e-ticaretin ekonomik etkisine bakıldığında ise, talebi ve tüketimi arttırarak ekonomiyi canlandırdığı belirtilmektedir (Jha, 2019).

E-ticaretin küresel çapta etkilediği coğrafyalardan kent ölçeğine inildiğinde, tüketici alışkanlıklarındaki değişimle birlikte artan çevrimiçi alışveriş, perakende sektörü işletmeleri için yeni iş modeline yönelik aksiyonları gerekli kılmıştır. 90’ların sonunda ilk kez kullanılmaya başlanan çevrimiçi mağazacılık ile tüketicilere çevrimiçi olarak sipariş ettikleri ürünlerin evlerine kadar getirilmesi veya ürünleri mağazadan veya belirlenmiş bir toplama noktasından teslim alma olanağı veren hizmetler kullanılmaya başlanmıştır (Saunders, 2018). 2009 yılına gelindiğinde ilk karanlık mağaza (dark store) Tesco tarafından Birleşik Krallık'ta açılmıştır (The Daily Telegraph, 2009). Karanlık mağaza, karanlık süpermarket veya "dotcom center" terimi, yalnızca çevrimiçi alışveriş için hizmet veren bir perakende satış mağazasını veya dağıtım merkezini ifade etmektedir. Halka açık olmayan karanlık bir süpermarketin içi, yiyecek ve diğer perakende ürünleri içeren raflardan oluşan koridorlarla geleneksel bir süpermarkete benzese de mağazalar ana cadde veya alışveriş merkezlerinde değil, daha çok iyi ulaşım bağlantıları için tercih edilen bölgelerde yer almaktadır (Anonim, 2021a).

Bakalis vd. (2020)'nin belirttiğine göre, süpermarket raf alanı her zaman sınırlı olduğundan geçmişte süpermarketlerde raf alanı elde etmek için mücadele eden küçük üreticiler, çevrimiçi alışveriş imkanları sayesinde görülebilir olmuş ve tüketicinin gıda ürünü seçimleri daha demokratikleşmiştir. Toplumun temel ihtiyaçlarını karşılamaya yönelik olan sektörün işleyişi ve başarısı, mekâna ve zamana göre şekillenen tüketici davranışlarına (Sheth, 2020) diğer bir deyişle talebe cevap verebilmesine göre belirlenmektedir (Grewal, Krishnan, Levy ve Munger, 2010; Hübner, Kuhn ve Sternbeck, 2013).

Pandemi sürecine ilişkin olarak, bulaşma riski nedeniyle uygulanan sosyal mesafe kuralları, karantina uygulamaları, evde geçirilen sürenin artması ve restoranların kapanması, oldukça karmaşık olan tüketici davranışlarını birçok açıdan değiştirerek yeni alışkanlıkların ortaya çıkmasına neden olmuştur (Borsellino, Kaliji ve Schimmenti, 2020; Li, Hallsworth ve Coca-Stefaniak, 2020). Özellikle pandeminin başlarında, stoklama, tüketicinin temel ve zorunlu ürünlere yönelmesi, çevrimiçi kanalların tercih edilmesi, yerel ve sağlıkı ürünlere artan talep, değişen marka tercihleri, alışverişte geçirilen sürenin azalması, alışveriş miktarının artması ve alışveriş yapılan yerin farklılaşması bu değişimlerin başında gelmektedir (Arora, Charm, Grimmelt, Ortega, Robinson, Sexauer ve Yamakawa, 2020; Wang, Xu, Schwartz, Ghosh ve Chen 2020; Martin-Neuninger ve Ruby, 2020; Borsellino vd., 2020; Li vd., 2020).

UNCTAD'ın 9 ülkeyi (Brezilya, Çin, Almanya, İtalya, Güney Kore, Rusya, Güney Afrika, İsviçre ve Türkiye) kapsayan COVID-19 ve çevrimiçi alışveriş ilişkisi analizinde, COVID-19 sırasında çevrimiçi alışverişteki artışların ülkeler arasında farklılık gösterdiği; en fazla artışın Çin ve Türkiye'de olduğu belirtilmiştir (United Nations Conference on Trade and Development [UNCTAD], 2020). Pandemi, pek çok sektörde olduğu gibi perakende sektöründe de dijitalleşme sürecini hızlandırmıştır (McKinsey \& Company, 2020a; Popov, 2021) çünkü e-ticaret yaygın olarak kalabalık olan yerlerde bulaşabilecek her türlü viral hastalık riskini azaltmaktadır.

Fiziksel perakendede maliyetlerin giderek artması, dijitalleşme ile beraber e-ticaretin büyümesi ve değişen tüketici davranışları, fiziksel perakendeciliğin geleceği hakkında çeşitli tartışmalara neden olurken, iş modelinde dönüşümler yaratmıştır (McKinsey \& Company, 2020b; KPMG, 2021). İşletmelerin mevcut kanallarına yeni kanallar ekleyerek tek kanallı modellerden, çoklu kanallara (multi-channel), oradan da 
bütüncül kanallara (omnichannel) geçişi, bu sürece uyum stratejileri arasında yer almaktadır (Verhoef, Kannan ve Inman, 2015).

\subsection{Perakendecilikte Tek Kanaldan Çok Kanala Yönelim}

Artan e-ticaretin, bir diğer kanalın -özellikle fiziksel kanalın- sonu olmadığına dair tartışmalar bulunmaktadır (Nielsen, 2015). Fiziksel olanla çevrimiçi kanalları birleştirmenin önemli bir strateji olduğu ve bunun hem işletmeler hem de müşteriler için tercih edilen bir model olduğu düşünülmektedir. Örneğin, Amazon'un 431 mağazası olan bir zinciri satın alması (Thompson, 2017), Çin'deki perakende markası JD'nin beş milyon mağaza inşa edeceğini duyurması gibi örnekler bu kapsamda değerlendirilebilir (Bala, 2020). Aynı zamanda, Wyman (2018)'nın yaptığı çalışmanın sonuçları, bütüncül kanallı (omnichannel) olmanın müşteri memnuniyet düzeyini yükselttiğini ortaya koymuştur. Bu çalışmaya göre, bunun temel nedeni müşterilerin içerik bilgisinin yanında, ürünle fiziksel temasa da önem vermesidir. Ancak çevrimiçi perakende deneyimlerinin de örneğin, siparişlerin hazırlanması ve teslimatına ilişkin artan maliyetler yanısıra yasal ve güvenlik sorunları gibi sorunları bulunmaktadır. Pandemiden bağımsız düşünüldüğünde, özellikle teslimatta müşterilerin evde beklemek zorunda olması veya ürünlerini belirli bir noktadan almaları, birçok müşteri için uygun ve tercih edilir olmamaktır. Gıda perakende özelinde ise, ortalama bir haftalık mağaza maliyetini \%10'u kadar artıran bir teslimat maliyeti konunun yaygınlaşmasında önemli bir engel oluşturmaktadır (Wyman, 2018).

Çok kanallı yapılarda maliyetlerinin yanı sıra, aynı anda faaliyete alınarak uygun iş modellerinin belirlenmesi de kolay bir süreç olmamaktadır (Hübner, Holzapfel ve Kuhn, 2016a). Çünkü kanallar arası gereklilikler farklılaşmakta ve işletmeler her kanalla uyumlu olabilecek modellere ihtiyaç duymaktadır (Lang, 2010). Örneğin çevrimiçi bir kanalı eklemek ve yönetmek, sistemi fiziksel olarak yönetmekten çok farkı bir şekilde yönetebilmeyi gerektirmektedir. Dağııımın ve iadenin kaynak (source) ve varış (destination) olarak nasıl organize edileceği en pahalı ve kritik operasyonlardan biridir. Buna bağlı olarak lojistik ve stok yönetim, rekabeti sağlayacak temel unsurlar haline gelir. Özellikle daha önce ürünlerin mağazaya ulaşmasının neredeyse son aşaması olduğu lojistik sistemler (Hübner vd., 2016a), çevrimiçi kanalın eklenmesiyle beraber yeniden organize olmak zorunda kalmışlardır. Bu nedenle hem daha az zaman kaybına yol açan, hem de daha düşük maliyetli stratejilerin benimsenmesi önemli olmaktadır (Lang, 2010; Hübner vd., 2016a).

Gıda perakende özelinde ise, e-ticaretin önemli bir kanal olmasına karşın görece sınırlı kaldığı bilinmektedir (Warschun'dan (2012) aktaran Campo ve Breugelmans, 2015; Pucci, 2021; Lang, 2010). Ancak sektörde görece sınırlı kalan e-ticaret payının, pandemi ile beraber ABD (Mercatus, 2020), ingiltere (Mintel, 2021; Gladman, 2021), Hindistan (USDA, 2021; Raguneethan, 2021; Kashyap, 2020) ve Çin (Anonim, 2021b) gibi ülkelerde önemli artış gösterdiği tespit edilmiştir. Örneğin ABD'de 2020 yılı için beklenen düzey olan \%4,3'den, pandemi ile birlikte $\% 10,2^{\prime}$ ye hızlı bir artış görülmektedir (Şekil 2). Yine aynı şekilden takip edildiği üzere, bu eğilimin gelecek için de devam edeceği ve 2025'de \%21,5'a ulaşacağı tahmin edilmektedir. Dolayısıyla, gıda perakende sektörüne çevrimiçi kanalların entegrasyonu, işletmelerin rekabet edebilmesinde oldukça kritik olmaktadır. Gıda perakendeciliğinde konuyu değerlendirirken daha önce bahsedilenlere paralel olarak 'işletme ölçeği' ve 'talep miktarı' olmak üzere iki yönden bakılabilir. Bu iki konuya ek olarak söz konusu gıda olduğunda ürünün yapısı da -kategorisidikkate alınmalıdır (Campo ve Breugelmans, 2015). Çevrimiçi perakendeciliğin gıdaya entegrasyonu hem tüketiciler hem de işletmeler için diğer ürünlerden farklı bir yaklaşım geliştirmeyi gerektirmektedir. Özellikle duyusal kategorilerde çevrimiçi kanalda (1) dayanıkı olmayan yiyeceklerin teslimatının hızıı bir şekilde ve teslimat sırasında ürünün kalitesini bozmayacak şekilde gerçekleştirilmesi (2) birçok taze ürün doğası gereği koku, his ve dokunma duyularını kullanarak seçilmeyi gerektirdiğinden (Hisano, 2020; Klepek ve Bauerová, 2020) bu konuları dikkate alarak organize edilmesi gerekmektedir. 
Şekil 2: Marketlerin Çevrimiçi Satışlarının Yıllık Bileşik Büyüme Oranı (ABD)

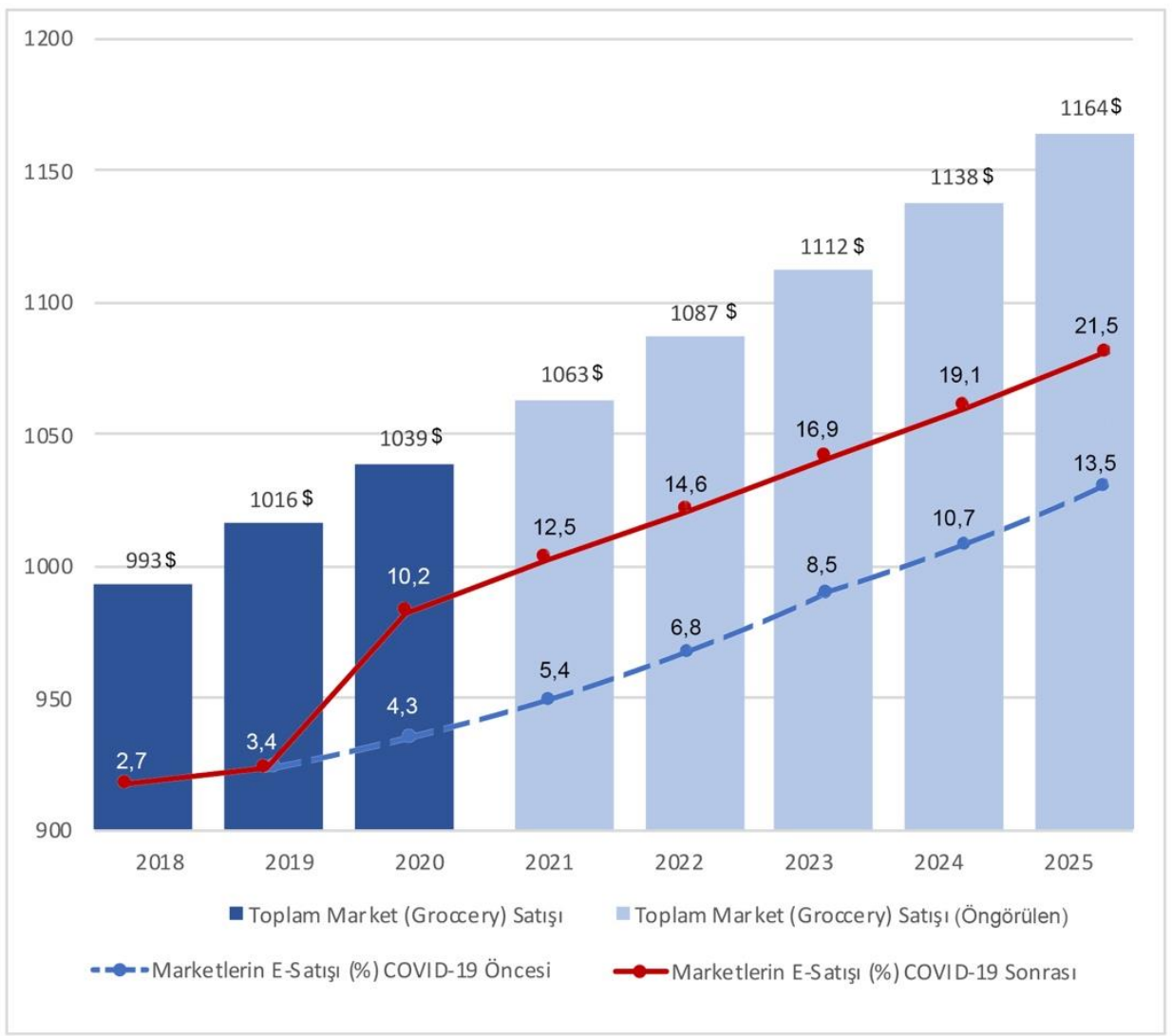

Kaynak: Mercatus, 2020

Gıda perakendede yaygın olan çevrimiçi iş modelleri incelendiğinde ise dört temel modelin ön plana çıktığı görülmektedir. İlk modelde, depo üzerinden müşterilere hizmet verilmesi amaçlanmaktadır. Temel olarak araçlarıyla gelen müşteriler arabalarından inmelerine gerek kalmadan kısa bir süre içinde alışverişlerini tamamlayabilmektedirler. İkinci model olan mağaza temelli tıklama ve teslim almada ise, belirli bir zamandan önce verilen siparişlerin önceden hazırlanarak aynı gün içinde müşteriler tarafından mağazalardan teslim alınmasına dayanmaktadır. Üçüncüsü genel olarak sadece çevrimiçi kanalı benimseyen perakendecilerin merkez bir depo üzerinden evlerine dağıtımı yapılan modeldir. Son olarak ise çevrimiçi pazara girmek isteyen geleneksel perakendecilerin ağırlıklı olarak tercih ettikleri model olan mağaza tabanlı ev teslimat modelidir (Delfmann, Albers, Müßig, Becker, Harung, Schöneseiffen ve Kukwa, 2011).

Modellerin tümünde özellikle siparişlerin çevrimiçi işlenmesi, e-ticaretin yaygınlaşmasında oldukça önemlidir. E-ticarette tüketiciler tarafından gerçekleştirilen siparişin, hazırlama, paketleme ve teslimatının; perakendeciler tarafından gerçekleştirilmesi gerekmekte, ancak bunun için gerekli lojistik operasyonlar zor ve maliyetli olmaktadır (Grant, Fernie ve Schulz, 2014; Hübner, Kuhn ve Wollenburg, 2016b; Kämäräinen ve Punakivi, 2002; Murphy, 2003). Bu durum iş modellerinin gelişmesini engellemekte ve çevrimiçi kanalı olan işletmelerin karlılığını sürdüremediği belirtilmektedir (Grant vd., 2014; Foley Retail Consulting, 2020). Bu noktada, çevrimiçi kanalda büyümenin nasıl sağlanabileceği tartışılan konuların başında gelmektedir. Ancak değişen dinamikler sonucunda, üreticiler veya çevrimiçi platformlar gibi yeni oyuncular, perakende sektörüne daha fazla girerek geleneksel perakendeye alternatif oluşturmaktadır. 
Şüphesiz yapılan bu tartışmalar, COVID-19 pandemisinin talepte yarattı̆̆ı etkiyle düşünülmeli ve eticarette ortaya çıkan bu fırsatın, sektörde uzun vadeli ve kalıcı bir değişim yaratıp yaratmayacağı ile ilişkili olarak değerlendirilmelidir (Dannenberg, Fuchs, Riedler ve Wiedemann, 2020).

\section{YÖNTEM}

Bu çalışma, pandemi öncesinde de gündemde olan çevrimiçi alışverişin, pandemi sürecinde gıda perakende sektörü işletmelerinin aksiyonlarını nasıl etkilediği sorusu ile yola çıkmaktadır. Çalışmanın odaklandığı organize gıda perakende sektöründe, yaygınlıkları, mağaza sayıları, sundukları ürün çeşitliliği, kapasiteleri, tedarik zinciri ve işletme modelleri açısından farklılık gösteren üç temel alt işletme grubu bulunmaktadır: indirim marketleri, yerel marketler, ulusal zincir marketler (Şekil 3). Buna göre farklı türde ve farklı kapasitelere sahip işletmeler üzerinden yapılacak bir analize uygun olarak, nitel araştırma yöntemlerinden 'çoklu vaka çalışması' yöntemi benimsenmiştir. Çoklu vaka çalışması, vakalar arasındaki benzerlik ve farklılıkların anlaşılmasına olanak sağlamaktadır (Baxter ve Jack, 2008; Stake (1995)'den aktaran Gustafsson, 2017). Çoklu vaka çalışması yönteminin kullanılması ile, olguların vakalarda -ki bu genellenebilir değerlendirme yapmaya da olanak tanır- nasıl farklılaştı̆̆ı ortaya konulabilecektir (Yin, 2003; Hafiz, 2008).

\section{Şekil 3: Gıda Perakende Sektörü Sınıflaması}

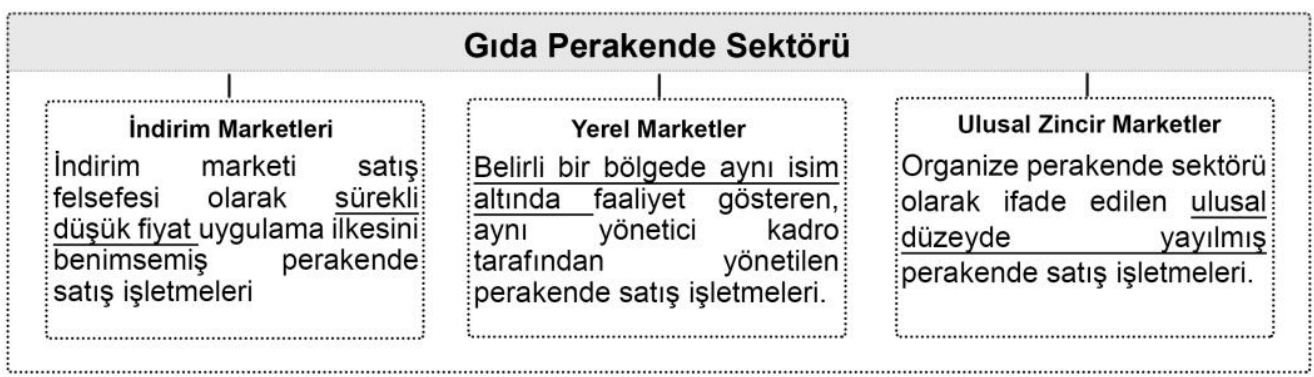

Kaynak: Türkiye Perakendeciler Federasyonu [TPF] (2020) ve Gürman (2006)'dan yararlanılarak yazarlar tarafından oluşturulmuştur.

Çalışma, Temmuz-Aralık 2020 tarihleri arasında, nüfus büyüklüğü ve ekonomisi ile (nüfusun \%18,6'sı (TÜiK, 2019); GSYH'nın \%31'i (TÜiK, 2018) Türkiye'nin en önemli metropol kenti olan İstanbul'da yürütülmüştür. Yukarıda belirtildiği gibi sektörde farklılık gösteren üç işletme grubunun, COVID-19 pandemisinden nasıl etkilendikleri ve ne tür uyum stratejileri geliştirdikleri araştırma kapsamında analiz edilmiştir.

Örneklem belirleme sürecinde, ilk olarak Maptriks² ile görüşme yapılmış ve gıda perakende sektörüne ilişkin veri tabanlarından yararlanılarak çalışmanın evreni oluşturulmuştur ${ }^{3}$. İstanbul'da marka sayıları ve mağaza sayısı açısından farklı dağılımlar gösteren gıda perakende sektöründe 125 farklı işletme markasının toplam 7217 mağazası bulunmaktadır. Marka sayısına göre işletmelerin \%93,6'sını yerel marketler, \%4'ünü indirim marketleri, \%2,4'ünü ulusal zincirler oluşturmaktadır. Ancak ulusal zincir ve indirim marketleri çok sayıdaki mağaza (şube) sayıları ile organize gıda perakende içinde \%84'lük bir kısmı oluşturmaktadır.

Nitel araştırmalarda örneklem büyüklüğünün kısıtlar çerçevesinde zengin ve derin bilginin üretilmesine olanak sağlayacak şekilde belirlenmesi önemlidir. Ayrıca, araştırmacıların analitik ve gözlemsel yeteneğine bağlı olarak da doyumluluk oranı önem kazanmaktadır (Baltacı, 2018). Bu kapsamda araştırmada, temsil düzeyi ve diğer kısıtlar göz önüne alınarak marka sayısı üzerinden tabakalı amaçlı örnekleme metodu ile İstanbul'da farklı yapı ve ölçeklerde olan 22 gıda perakende işletmesi ' 'analiz birimi' olarak seçilmiştir (Tablo 1). Tabakalı amaçlı örneklem metodunun kullanılmasının temel sebebi ana kütlenin temsiliyetini sağlamakla beraber tabakalar arası farklılıkları ve benzerlikleri ortaya koymaktır. 
Buna göre, tabakaları oluşturan temel değişken gıda perakende sektöründeki üç farklı işletme kategorisidir (yerel, indirim, ulusal zincir marketleri) ve yapılan görüşme sayısı Tablo 1'de sunulmaktadır.

Tablo 1: Görüşme Yapılan İşletmelerin Dağııımı

\begin{tabular}{lc}
\hline \multicolumn{1}{c}{ Gruplar } & İşletme Sayısı \\
\hline İndirim Marketleri & 2 \\
Yerel Marketler & 17 \\
Ulusal Zincirler & 3 \\
Toplam & 22 \\
\hline
\end{tabular}

22 işletmenin yetkili kişisiyle (işletmenin sahibi ya da yönetici pozisyonunda çalışan kişilerle) ${ }^{5}$ 02.07.2020-11.11.2020 tarihleri arasında yarı-yapılandırılmış görüşme tekniği kullanılarak (yüz yüze ya da çevrimiçí) veriler toplanmış ve analiz edilmiştir. Sonraki bölümde, gıda perakende işletmeleri ile yapılan görüşmelere dayalı bulgular sunulmaktadır. Görüşme yapılan işletmelere kodlar verilerek ${ }^{7}$, görüşme notlarının doğrudan aktarımı yöntemi izlenmiştir. Bu araştırma için İstanbul Teknik Üniversitesi Sosyal ve Beşeri Bilimler Insan Deneyleri Etik Kurulu'nun 11 Haziran 2020 tarih ve 146 sayılı kararı ile etik kurul onayı alınmıştır.

\section{PANDEMI SÜRECINDE ARTAN ÇEVRIMIiçi ALIŞVERIŞiN GIDA PERAKENDE SEKTÖRÜNE ETKILERININ ANALIZI VE BULGULAR}

Araştırma bulguları, öncelikle örneklemde yer alan gıda perakende sektörü işletmelerinin, pandemi etkisi ile ne ölçüde çevrimiçi satışa yöneldikleri ve bu yeni durumun ortaya çıkardığı sorun alanlarına ilişkin bir değerlendirmeyi içermektedir. Sonrasında, işletmelerin dijitalleşme konusunda sektörün geleceğine ilişkin görüş ve beklentileri ele alınmıştır.

\subsection{Pandemi Etkisi ile Çevrimiçi Kanala Yönelme Konusundaki Deneyimler ve Karşılaşılan Zorluklar}

Çalışma kapsamında görüşülen gıda perakende işletmelerinin, pandemi öncesinde müşterilerine ağırlıklı olarak mağazadan doğrudan satış yoluyla hizmet verdiği tespit edilmiştir. Yerel perakende işletmeleri için iki eğilimin olduğu söylenebilir. Bunlardan ilki, yatırım ve işletme maliyetleri, müşteri profili, operasyonel zorluklar ve işletme yönetiminin e-ticarete ilişkin yaklaşımı nedeniyle çevrimiçi kanala geçmeyenler iken, ikincisi ise iş modeli olarak çevrimiçi kanalı da ekleyen işletmelerdir. Pandemi sırasında sanal alışveriş kanalı olmayan yerel marketler için WhatsApp ve Telefon sipariş hatlarının, hızlıca devreye alınabilmesi ve maliyetinin görece daha az olması alternatif kanallar olarak değerlendirilmiştir. Sanal alışveriş konusunda, diğer yerel marketlere göre daha erken hamle yapan ve sanal siparişe 2015 yılında başlayan Y.13.C (Yerel market, 7 mağaza)'nin evlere kapanma esnasında internet siparişlerinin payı $\% 1$ 'den $\% 15^{\prime}$ e çıkmıştır. İşletme yöneticileri, e-ticareti telefon-WhatsApp siparişlerinden şu şekilde ayırmaktadır: "Telefon-WhatsApp'ta sipariş veren genelde çok yakın komşu oluyor. Onları hemen bir arkadaş arabaya atıp götürebiliyor. Çevrimiçi için; siparişler hazırlanıyor, aynı bölgede olanlar toplu çıkıyor. O yüzden orada bekleme süresi biraz daha uzayabiliyor."' (Y.13.C).

Görüşülen her firma, pandeminin sanal alışverişin gerekliliğini bir kez daha vurgulamış olduğu fikrini paylaşsa da pandemi öncesinde hâlihazırda sanal alışveriş altyapısı olanlar hariç, hiçbir gıda perakendecisinin (tek bir istisna hariç (i.1, indirim marketi, 10000 mağaza), bu süreçte iş birlikleri kurmak dışında sıfırdan e-ticaret yatırımına yönelmemiş olduğu görülmüştür. Şüphesiz bu durum, e-ticaret yatırımlarının kısa sürede hayata geçirilmesinin zor ve yatııım maliyetinin yüksek olması ile de doğrudan ilişkilidir. Kurulan iş birlikleri Marketyo ya da Marul gibi, altyapısı olmayan marketlere yazılım hizmeti 
sunan ve marketlerin çevrimiçi kanalda hizmet vermesini sağlayan platformlarla gerçekleştirilmektedir. Yerel perakendeciler, Marul.com gibi çevrimiçi alışveriş platformu sunan şirketlerle yaptıkları iş birliklerinin de sektördeki rekabette yeterince etkili olamadığını ve satışlarının çok küçük bir kısmının bu platformlar üzerinden gerçekleştiğini belirtmişlerdir. Yerel marketlerin çevrimiçi satış için altyapılarının olmaması, büyük ölçüde pandemi öncesinde buna ihtiyaç duymamış olmalarından kaynaklanmaktadır.

Çevrimiçi satışlara mesafeli yaklaşan ve zaten pandeminin ilk döneminde fiziksel mağazacılıktan kazanan işletmelere rağmen, ulusal zincir marketleri için pandemi mevcut kapasiteyi arttırmaya yönelik aksiyonları hızlandırmıştır. E-ticaret geçmişi çok eskiye dayanan U.1 (Ulusal zincir, 342 mağaza)'in pandemi öncesinde yalnızca \%7 olan çevrimiçi alışveriş oranı, pandeminin birinci döneminde \%25’e kadar çıkmış, 2. dönemde yine pandemi öncesine göre daha yüksek bir oranda, \%13'de seyretmiştir (Tablo 2). COVID-19 salgını ile son dönemde artan taleplere daha hızlı ve kesintisiz cevap verebilmek için yeni bir çalışma modelini devreye alan U.1, alışveriş merkezlerinde yer alan büyük ölçekli belirli mağazalarını, sadece eticaret hizmeti veren karanlık mağazalara (dark store) dönüştürmüştür. Açıklanan rakamlara göre fiziksel ve çevrimiçi satışı birlikte gerçekleştiren mağazalara kıyasla, karanlık mağazalarla e-ticaret hizmeti U.1'in kapasitesini 5 kat arttırmıştır (Habertürk, 2020).

Tablo 2: U.1'in Müşteri Hizmet Kanalları

\begin{tabular}{ccc}
\hline Pandemi Öncesi & $\begin{array}{c}\text { Pandemi 1. Evre } \\
\text { (Mart, Nisan, Mayıs) }\end{array}$ & $\begin{array}{c}\text { Pandemi 2. Evre } \\
\text { (Haziran, Temmuz, Ağustos) }\end{array}$ \\
\hline Mağaza: \%93 & Mağaza: \%75 & Mağaza: \%87 \\
İnternet: \%7 & İnternet: \%25 & Internet: \%13 \\
\hline
\end{tabular}

Kaynak: Tablo, görüşme sonuçlarına dayanarak oluşturulmuştur.

Ayrıca U.1, uzun süredir internet satışı yanı sıra, telefon ve WhatsApp uygulamasını da kullandıklarını belirtmiştir: "Sanal alışveriş uygulamamız 25 yıllık. Ayrıca mağazalarımızda hem WhatsApp hem telefon uygulaması kullanılmaktadır. Ama telefon ve WhatsApp için ortak ve organize bir sistem yok. Kimi mağazalarımız bu hizmeti müssteri talebine istinaden vermektedir. Çünkü biz müşterilerimizle sürekli iletişim halinde olan bir şirketiz. Mağaza talebi de ona göre gelişsmektedir.".

Öte yandan, gerek mağaza sayılarının fazlalı̆̆ı, gerekse ciroları ile pazarda önemli paya sahip olan ulusal zincir ve indirim marketlerinin çevrimiçi alışverişe yönelik mesafeli duruşuna ilişkin görüşleri ise, zaten cirolarını büyük bölümünü fiziksel mağazaclık ile gerçekleştirmeleri ve çevrimiçi alışverişin organizasyon zorlukları ve maliyetlerine işaret etmeleri şeklindedir: "Bizim ciromuzun online'daki payı sadece \%1.5-2'lerdedir... Mevcut altyapımızla çevrimiçi alışverişsin payı \%5'i aşmayacaktır. Sanal alışverişte en büyük sorun lojistik faaliyetlerdir, çünkü bir günde ulaştırabildiğiniz siparişs sayısı lojistiğe bağlıdır. Sorunların azaltılması için depo kapasitesi artırılmalıdır. Fakat genişleme potansiyelinin farkındayız. Bizim gibi büyük cirolu bir firma için sanal alışverişin payı ve getirisi düşük, bu yüzden yatırımlar konusunda daha çekimseriz." (i.1, indirim marketi, 10000 mağaza).

"Online iş modellerinin 'handikapları' var. Biz bu nedenle sanal alışverişe ne ihtiyaç duyduk, ne de gerek gördük. Çünkü zaten pandemi sürecinde talep normalin çok üstünde artmış durumdaydı. Bütün perakendeciler raf doluluk oranları, çalışan memnuniyeti gibi birçok açıdan mağazadaki performanslarında ciddi kayıplar vermişken başka kanallardan şartları zorlamak, ciddi bir çalışan verimsizliğine yol açabilirdi. Ki zaten yol açtı bazı perakendecilerde... Hem de bir işi yapıyorken o işin hakkını vermek lazım. Yani iki işi yarım yapmaktansa, bir işi tam yapmak bizim için daha değerli." (U.3, Ulusal Zincir, 82 mağaza).

Bir indirim marketi olan i.1 (İndirim marketi, 10000 mağaza) ise var olan internet sitesi satışına ek olarak bu süreçte mobil uygulama yatırımı yapmıs ve kısa zamanda kullanıma açmıştır: "2018 sonuna doğru e-ticarete web üzerinden başlamıştık, ama oradaki format Amazon gibi depodan yapılıyordu ve bir 
mobil uygulamamız yoktu. Aralık itibariyle on bin markete ulaştık. Türkiye'nin 975 ilçesinin hepsinde mağazamız var. Dolayısılyla marketten müșteriye sevkiyat düşüncemiz vardı. 2020'de etap etap yapacağımız bu operasyonu pandemi hızlandırdı. Pandeminin en önemli etkilerinden biri bu mobil uygulamaya geçişin hızlanmasıydı diyebiliriz. 28 nisanda dijitalleşme sürecine başlayıp, 1 eylülde tamamladık. Bizim farkımız bu işi çok hızlı yapmamız! Markette ne varsa, mobil uygulamamızda mevcut. Kaydolup, teslimat zamanını seçiyorsunuz o kadar." (i.1).

Pandemi öncesinde çevrimiçi alışverişe yatııım yapmış olan gıda perakendecilerinin ortak görüşü, bu süreçte önceden hazırlıklı olmanın çok faydasını gördükleri yönündedir. Ayrıca pandemi döneminde pek çok sektörde işgücü kayıpları yaşanırken (kapanan işletmeler, zorunlu yıllık izne çıkartılan çalışanlar gibi), gıda perakende sektöründe talep artışına ve özellikle e-ticaret satışındaki artışa bağlı olarak depo ve dağıtımda çalışan sayısının arttığı belirtilmiştir.

\subsection{Dijitalleşme ve Sektörün Geleceğine Ilişkin Öngörüler}

İşletmelerin dijitalleşme konusunda sektörün geleceğine ilişkin görüş ve beklentilerine bakıldığında ise, pandemi ile değişen tüketici tercihleri ve çevrimiçi ticarette yaşanan gelişmelere bağlı olarak çoklu kanalların tercih edildiği ve edileceği öngörülmektedir.

"GIda perakendeciliği hem fiziksel hem de sanal olarak devam edecek. Bu nedenle hem depodan doğrudan dağıtım olacak hem de mağazadan satın alan müşteriler olacak." (Y.17.D, yerel market, 2 mağaza).

Yapılan görüşmelerde indirim marketlerden i.1 (Indirim marketi, 10000 mağaza), dünyada gıda perakendeciliği özelinde e-ticaretin en gelişmiş pazarlarda bile sınırı kaldığını belirtmiştir. i.2 (İndirim marketi, 7920 mağaza) de aynı düşünceyi vurgulamış ve bu nedenle bu alana yatııım yapmadıklarını açıklamışlardır. Fakat i.2'nin aksine i.1 pandemi döneminde hızla mobil uygulamaya yatırım yapmayı tercih etmiştir. Neden bu yatırımı yaptıklarına açıklama olarak ise kısa vadede yüksek bir kâr payı getirmese de uzun vadede sektörün çevrimiçi alana yönelmesinin kaçınılmaz olduğunu ve erken hamle yapanların daha avantajlı olacakları görüşünü bildirmişlerdir.

Gıda perakendede her ne kadar mağazadan alışveriş büyük oranda tercih ediliyor olsa da görüşme yapılan işletmeler, pandeminin sektörde sanal mağazacılığa geçişi hızlandırdı̆̆ını düşünmektedirler. Y.3.B (Yerel market, 45 mağaza) görüşünü, "Bize pandeminin en büyük etkisi şu oldu; e-ticaretin ne kadar önemli olduğunu, artık bu alana girmemiz gerektiğini görmüş olduk" şeklinde ifade etmiştir. Pandemi ile birlikte e-ticarette yaşanan artışın pandemi sonrasında da süreceği, bu kanalın sektörün bir parçası olacağı ve sektördeki rekabet açısından oyuncuların da bu değişime uyum sağlaması gerektiğine değinilmiştir.

Gelecekte sektörün çevrimiçi olarak ilerleyen kolunun mağazadan değil de depodan dağıtıma yöneleceği düşünülmektedir. Şüphesiz bu dağıtım modelini, ilgili markanın ölçeğiyle ilişkili mevcut eticaret hacmi ve gelecek için olası potansiyel hacimle birlikte değerlendirmek gerekmektedir. Mağazada müşterilerin arasında dolaşan toplayıcılar ('picker') aracılığıyla sipariş hazırlamanın verimli olmadığını; sanal mağazacılığın bu amaca uygun hazırlanan depolardan yapılması gerektiğini düşünmektedirler.

"Bu aralar karanlık mağaza (dark-store) için çalışıyoruz. Yatırımlarımız o yönde. Şu anda toplayıcılarımız mağazadan toplayıp götürüyor siparişleri" (Y.15.C, yerel market, 4 mağaza).

“3 yıl içinde Türkiye'deki toplam gıda perakende alışverişinin yarıdan fazlasının sanal ortamda olacağına inanıyorum. Depodan dağıtım olacak. Avrupa'da kargo sistemi çok farklı bir yerde. Hem daha ucuz hem daha yaygın. Türkiye'de de kargoculuk sisteminin daha ucuzlayıp, kargo firmalarının çoğalıp yaygınlaşmasıyla lojistik maliyetleri düşünce, sektör sanal markete yönelecek" (Y.12.C, yerel market, 7 mağaza).

"Biz depodan dağıtıma ciddi ciddi yönelmiştik. Sadece depo tutup, 'Getir' gibi dağıtım yapacaktık. Mağaza değil de daha profesyonel olup depodan sevkiyat düşünüyorduk. Maliyetlerin zirve yapması buna engel oldu" (Y.14.C, yerel market, 6 mağaza). 
Karanlık mağaza (dark-store) olarak adlandırılan dağıtım modelinin hız ve maliyet açısından çevrimiçi kanalı destekleyeceği düşünülmektedir. E-ticaretin iyi bir altyapı gerektirdiği, ancak bu altyapının oldukça pahalı olması, özellikle finansal problemleri olan daha küçük gıda perakendecileri için aşılması zor bir durum olarak tanımlanabilir. Diğer bir kritik konu da çevrimiçi kanalda görünür olma zorunluluğudur. Görüşmelerden çıkan sonuçlardan biri de yaygın olan şatış kanallarına (Trendyol Marketl, HepsiMarket) son dönemde eklenen gıda kategorisi sayesinde görece büyük marketler daha görünür olurken, bu kanallara bütçe ayırmakta zorluk yaşadığı için iş birliği yapamayan küçük marketlerin, e-ticarette rekabet edilebilirliklerinin daha da zorlaştığı şeklindedir.

\section{SONUÇ}

$\mathrm{Bu}$ çalışma, organize gıda perakende işletmelerinin pandemi sürecinden nasıl etkilendiğine çevrimiçi alışverişe olan talepteki artışı odağa alarak bakmaktadır. Dünyadaki eğilimlerin, Türkiye'deki işletmeler için ne ölçüde geçerli olduğu ya da farklılıklar ortaya koyduğu yönüyle literatüre katkı sunulması amaçlanmıştır.

İlk aylarda uygulanan karantina önlemleri ile pek çok perakende sektörü talep yönünde çok belirgin bir daralma yaşarken, gıda perakende sektörü ise tam tersi olarak panik alımlar nedeniyle oluşan aşırı talebi yönetmek zorunda kalmıştır. Aynı zamanda, pandeminin tüketici davranışlarında yarattığı etkinin kalıcı olacağı ve çevrimiçi kanala yönelimi hızlandıracağı öngörüsü de, gıda perakende işletmelerinin iş modellerini değiştireceğini işaret etmektedir.

Bu araştırma kapsamında görüşülen işletmeler içinde, iş modellerinde değişikliğe gitmekten kaçınanlar (özellikle yerel marketlerin çoğunluğu) olsa da, dünyadaki gelişmelere paralel olarak özellikle çevrimiçi alışverişin giderek daha yüksek pazar payına sahip olacağı beklenmektedir. Pandemi sürecinde yaşanan olağanüstü koşullar, daha önceden bu alanda yatırım yapmış olan veya yatırım yapmayı planlayan (görüşülen iki ulusal zincir, bir indirim marketi ve yerel marketlerin sınırlı bir bölümü) marketlerin dijital dönüşüm sürecini hızlandırmıştır. Çevrimiçi iş modeli, kuşkusuz tüketici alışveriş alışkanlıklarının değişimi ile ilişkidir. Bu süreçte, belki daha önce çevrimiçi alışveriş kanallarını kullanmayan birçok kişi, bu kanalları salgın önlemleri dolayısıyla kullanmak zorunda kalmıştır. Araştırmanın yürütüldüğü İstanbul, Türkiye'nin en büyük nüfusa sahip kenti olarak, özelikle genç nüfusun teknoloji kullanımına yatkınlığı ile çevrimiçi alışverişte tüketici davranışlarının kalıcılığı açısından önemli potansiyel sunmaktadır. Dolayısıyla, işletmelerin bu eğilimi dikkate alan yatırıma yönelmeleri önemli olmaktadır. Ayrıca, pandemi koşulları Verhoef $v d$. (2015)'nin pandemi öncesinde tespit etmiş olduğu perakendede tek kanallı modelden çoklu kanallara geçiş eğilimini hızlandırmıştır.

Süpermarket ürünleri için çevrimiçi alışverişin müşteriler arasında daha fazla kabul görmesi ve yaygınlaşması, indirim marketlerinin baskısıyla yerleşim odaklı rekabet stratejisi artık avantajlı olmayan yerel marketler için, yeni bir rekabet avantajı oluşturabilir. Fakat araştırma bulguları, yerel marketlerin bu alanda yatırım yapmak için henüz istekli olmadıklarını göstermektedir. Bunun nedenleri arasında, bu kanalın operasyon zorluğu ve maliyeti (Hübner vd, 2016b) ile ilişkili olarak işletmelerin sermaye kısıtları başta gelmektedir. Görüşme yapılan işletmelerde, bu konudaki girişimlerin, büyük ölçüde maliyetlerin düşmesine bağlı olduğu belirtilmiştir. Öte yandan, Hisano (2020) ve Klepek ve Bauerová (2020)’nın da belirttiği gibi tüketicilerin taze meyve-sebzeyi görerek alma eğilimleri de önemli bir neden olarak karşımıza çıkmaktadır. Türkiye örneğinde, mahalle düzeyinde yürüyüş mesafesinde konumlanan marketlerin, pandeminin en yoğun kapanma döneminde bile hizmet sunmaları ve market alışverişi için sokağa çıkılabilmesi, tüketicinin mağazadan alışverişine devamında önemli bir etken olmuştur. Ayrıca, mahalle düzeyinde hizmet veren marketler, alışverişin toplumda bir tür sosyalleşme aracı olarak görüldüğünü ve müşterilerini bire bir tanıdıklarını belirterek, fiziksel mağazacılık dışındaki kanallara yönelme gereği duymadıklarını ifade etmişlerdir. Ancak, her ne kadar Lang (2010)'ın vurguladığı gibi kanallar arası gereklilikler farklı olsa da, gıda perakende sektöründe çevrimiçi ve fiziksel alışverişlerin devam edeceği çoklu kanalların gelecekte daha da önem kazanacağı anlaşılmaktadır. Öte yandan, fiziksel mağazacılık dışında, çevrimiçi satışların artması ise bugünküne göre daha farklı mekânsal ihtiyaçları ortaya çıkaracaktır. 
Çevrimiçi satış ürünlerinin mağaza yerine depodan dağııımı, daha fazla depo alanlarına gereksinimi ortaya çıkaracak ve dağıtım maliyetleri açısından daha çok mahalle ölçeğinde karanlık mağazalara ihtiyaç olacaktır. Çevrimiçi alışverişin artmasının sektörün genelindeki diğer önemli etkileri, gerek işletme bünyesinde dağııım operasyonları için istihdam artı̧̧ı getirmesi, gerekse dağııımda yeni iş birliklerinin (getir, trendyol gibi) ortaya çıkması şeklinde görülmektedir. Dağıtımda iş birlikleri ve rota optimizasyonu konusu gerek çevreye verilen zarar gerekse zaman ve maliyet açısından işletmeler için önem kazanmaktadır.

Yeni dijital iş modelleri, gıda perakendeciliğini, geleneksel doğrusal yapıdan, her bir bileşen grubunun doğrudan nihai tüketiciyle bağlantı kurmasına izin veren ağ yapısına doğru değiştirmektedir. Özellikle çevrimiçi alışverişin de giderek yaygınlaş̧ığı bu dönemde aracılarından olabildiğince arınmış, dar boğazdan kurtulmuş ve kısalmış bir tedarik zincirinin gıda perakendeciliğinin kaçınılmaz geleceğini oluşturacağı öngörülmektedir (Bakalis $v d, 2020$ ). Pandemi ile ortaya çıkan yerelleşme fırsatları doğru kullanılırsa, gıda perakende zincirlerinde merkezileştirme ile ilişkili dezavantajlar ve riskler azaltılabilir. Ayrıca, tüketicilere yakın konumlanan küçük ölçekli tesisler, depolama ve nakliye maliyetlerini düşürerek, çevresel etkileri azaltmaya yardımcı olabilir.

Bu makale, organize gıda perakende sektöründe iş modellerinin tedariği de kapsayacak şekilde pandemiden nasıl etkilendiğini ele alan araştırma projesinin, çevrimiçi alışverişe yönelim karşısındaki deneyimleri keşfetmek bölümüne odaklanmaktadır. Ayrıca, gıda perakendenin pandemi sürecinde tedarik zincirini nasıl yönettiği de ayrı bir çalışma konusu olarak ele alınacaktır. Diğer yandan, bu çalışma kapsamında ele alınan organize gıda perakende işletmeleri, sektördeki oyuncuların bir bölümünü oluşturmaktadır. Pandemi etkileri ve sonrasına ilişkin, sektörün diğer oyuncularının da incelenmesi gelecekte yapılacak çalışmalar için önerilmektedir.

\section{NOTLAR}

12020 dünyanın en büyük perakende şirketleri sıralamasında 510,33 milyar dolar gelirle WalMart birinci iken; 232,88 milyar dolar gelirle Amazon ikinci, 123,25 milyar dolar gelirle LiDL'ın da dahil olduğu Schwarz Grup üçüncü; 89,81 milyar dolar gelirle Carrefour yedinci ve 91,90 milyar dolar gelirle ALDi sekizinci sıradadır (National Retail Fedaration, 2020).

2 Web adresi: https://maptriks.com/tr/

3 illgili veriler 2020'nin dördüncü ayında temin edilmiştir.

${ }^{4}$ Aynı zamanda işletmelerin genel merkezi ile görüşmeler yapıldığından, çalışma kapsamında örnekleme dahil olan 22 işletme \%57'lik bir orana karşılık gelmektedir (bir markanın çok sayıda mağazası olması nedeniyle).

${ }^{5}$ Çalışma evreninin iletişim adresleri ve konumlarına ilişkin bir tablo hazırlanarak görüşülmek istenilen işletmelere mail ve telefonla ulaşılmıştır.

${ }^{6}$ Çalışmada yapılan görüşmelerin $15^{\prime} i$ yüz yüze, 7 'si çevrimiçi yapılmıştır. İki farklı yöntemle yapılması görüşmecilerin tercihlerinden kaynaklanmaktadır.

${ }^{7}$ Kodlardaki Y: yerel marketleri, i: indirim marketlerini, U: ulusal zincirleri işaret etmektedir. 


\begin{tabular}{|c|c|c|c|c|c|}
\hline Türü & Mağaza Sayısı & $\begin{array}{c}\text { Faaliyet Gösterdiği il } \\
\text { Sayısı }\end{array}$ & $\begin{array}{c}\text { Çalışan Sayısı } \\
\text { (Toplam) }\end{array}$ & $\begin{array}{c}\text { Depo Sayısı } \\
\text { (Toplam) }\end{array}$ & Kodu \\
\hline İndirim Marketi & 10.000 (Türkiye) & 81 & 59.000 & 50 & i.1 \\
\hline İndirim Marketi & 7.920 (Türkiye) & 81 & 52.000 & 60 & i. 2 \\
\hline Ulusal Zincir & 342 & 81 & 45.000 & bilinmiyor & U.1 \\
\hline Ulusal Zincir & 260 & 52 & 11.059 & 12 & U.2 \\
\hline Ulusal Zincir & 82 & 11 & 3.550 & bilinmiyor & U.3 \\
\hline Yerel Market & 175 & 79 & bilinmiyor & bilinmiyor & Y.1.A \\
\hline Yerel Market & 58 & 5 & 4.500 & 5 & Y.2.A \\
\hline Yerel Market & 45 & 1 & 845 & 1 & Y.3.B \\
\hline Yerel Market & 31 & 2 & 830 & 1 & Y.4.B \\
\hline Yerel Market & 27 & 1 & 632 & 1 & Y.5.B \\
\hline Yerel Market & 22 & 1 & 500 & 1 & Y.6.B \\
\hline Yerel Market & 11 & 1 & 450 & 1 & Y.7.C \\
\hline Yerel Market & 11 & 1 & 250 & 1 & Y.8.C \\
\hline Yerel Market & 11 & 1 & 30 & 1 & Y.9.C \\
\hline Yerel Market & 8 & 1 & 130 & 2 & Y.10.C \\
\hline Yerel Market & 8 & 1 & 174 & 1 & Y.11.C \\
\hline Yerel Market & 7 & 1 & 54 & 3 & Y.12.C \\
\hline Yerel Market & 7 & 1 & 250 & 2 & Y.13.C \\
\hline Yerel Market & 6 & 1 & 85 & 4 (mağaza) & Y.14.C \\
\hline Yerel Market & 4 & 1 & 52 & 2 & Y.15.C \\
\hline Yerel Market & 2 & 1 & 42 & 2 mağaza) & Y.16.D \\
\hline Yerel Market & 2 & 1 & 56 & 2 & Y.17.D \\
\hline
\end{tabular}

\section{YAZAR BEYANI}

\section{Araştırma ve Yayın Etiği Beyanı}

Bu çalışma bilimsel araştırma ve yayın etiği kurallarına uygun olarak hazırlanmıştır.

\section{Etik Kurul Onayı}

Bu araştırma için İstanbul Teknik Üniversitesi Sosyal ve Beşeri Bilimler İnsan Deneyleri Etik Kurulu’nun 11 Haziran 2020 tarih ve 146 sayılı kararı ile etik kurul onayı alınmıştır.

\section{Yazar Katkıları}

Yazarlar çalışmaya eşit oranda katkıda bulunmuştur.

\section{Çıkar Çatışması}

Yazarlar açısından ya da üçüncü taraflar açısından çalışmadan kaynaklı çıkar çatışması bulunmamaktadır

\section{Destek Beyanı}

Bu çalışma, TÜBiTAK tarafından desteklenen 1001 Programı kapsamında 120 K312 numaralı projeden üretilmiştir.

\section{Teşekkür}

Bu makale TÜBiTAK 1001 Projesi olarak desteklenen, COVID-19 Pandemisinin Gıda Perakende Sektörüne Etkilerinin Analizi ve Geleceğe Yönelik Çözüm Önerilerinin Geliştirilmesi projesi kapsamında üretilmiştir. Projeye verdiği destekten ötürü TÜBiTAK'a teşekkürlerimizi sunarı. 


\section{KAYNAKÇA}

Akbudak, N., Ş. E. N. Özgür (2021), Covıd-19 Salgın Sürecinde Globalgap. Türkiye Tarımsal Araştırmalar Dergisi, 8(2), 248-255.

Akkan, E., M. Bozkurt (2020), COVID-19 Süreci ve Sürdürülebilirlikte Sosyal Boyutun Önemi: Türkiye'de Faaliyet Gösteren Gıda Perakendecilerinin Finansal Olmayan Raporları Üzerine Bir İçerik Analizi, Sosyal Bilimler Araştırmaları Dergisi, 15(2), 536-547.

Alanlar, E. (2021), Pazar Sepeti Analizi ile Birliktelik Kurallarının Belirlenmesi: Perakende Sektöründe Covid-19 Etkisi, Karabük Üniversitesi (Yüksek Lisans Tezi).

Anonim (2020a), TAMPF - Nielsen Perakende Ciro Endeksi sonuçları açıklandı, Perekend.org. https://www.perakende.org/tampf-nielsen-perakende-ciro-endeksi-sonuclari-aciklandi, E.T.: 28.09.2020.

Anonim (2020b), Impact of COVID-19 on the food industry, Foodware 365. https://www.foodware365.com/en/news/knowledge-base/2020/the-impact-of-covid-19-on-foodcompanies/, E.T.: 28.04.2020.

Anonim (2020c), Retail E-commerce Sales Worldwide from 2014 to 2023 Statista, https://www.statista.com/statistics/379046/worldwide-retail-e-commerce-sales/, E.T.: 12.10.2020.

Anonim (2021a), The Concept of "Dark Stores" and why retailers need to be aware of them https://qvalon.com/blog/the-concept-of-dark-stores/, E.T.: 22.11.2021

Anonim (2021b), What's next for the online grocery market in China after the stay-at-home economy slows? https://daxueconsulting.com/online-grocery-market-in-china/ E.T.: 12.10.2021.

Arora, N., T. Charm, A. Grimmelt, M. Ortega, K. Robinson, C. Sexauer, N. Yamakawa (2020), A Global view of how Consumer Behavior is Changing Amid COVID-19, National Crowdfunding \& Fintech Association. https://ncfacanada.org/a-global-view-of-how-consumer-behavior-is-changing-amid-covid-19/, E.T.: 20.12.2020.

Bakalis, S., V. P. Valdramidis, D. Argyropoulos, L. Ahrne, J. Chen, P.J. Cullen, E. Cummins, A. K. Datta, C. Emmanouilidis, T. Foster, P.J. Fryer, O. Gouseti, A. Hospido, K. Knoerzer, A. LeBail, A. G. Marangoni, R. Pingfan, O. K. Schlüter, P. Taoukis, E. Xanthakis, J. Van Impe (2020), “Perspectives from CO+RE: How COVID-19 changed our food systems and food security paradigms", Current Research in Food Science, 3, 166-172.

Bala, S. (2020), JD.com Wants a Network of 5 Million Stores as E-Commerce Battle heats up, CNBC.https://www.cnbc.com/2020/11/12/idcom-wants-network-of-5-million-physical-stores-inchina.html, E.T.: 25.12.2020.

Baltacı, A. (2018), "Nitel Araştırmalarda Örnekleme Yöntemleri ve Örnek Hacmi Sorunsalı Üzerine Kavramsal Bir İnceleme", Bitlis Eren Üniversitesi Sosyal Bilimler Dergisi, 7(1), 231-274.

Baxter, P., \& Jack, S. (2008), "Qualitative Case Study Methodology: Study Design and Implementation for Novice Researchers", The Qualitative Report, 13(4), 544-556.

Bloomberg (2018), Daron Acemoğlu'na Göre İşsizliği Etkileyecek 2 Teknoloji, Bloomberg, https://businessht.bloomberght.com/ekonomi/haber/2008447-daron-acemoglu-na-gore-issizligietkileyecek-2-teknoloji, E.T.: 03.02.2021.

Borsellino, V., S. A. Kaliji, E. Schimmenti (2020), “COVID-19 Drives Consumer Behaviour and Agro-Food Markets Towards Healthier and More Sustainable Patterns", Sustainability (Switzerland), 12(20), 1-26.

Campo K., E. Breugelmans (2015), "Buying Groceries in Brick and Click Stores: Category Allocation Decisions and The Moderating Effect of Online Buying Experience", Forthcoming in Journal of Interactive Marketing, 31, 6378.

Dannenberg, P., M. Fuchs, T. Riedler, C. Wiedemann (2020), “Digital Transition by COVID-19 Pandemic? The German Food Online Retail", Tijdschrift Voor Economische En Sociale Geografie, 111(3), 543-560.

Delfmann, W., S. Albers, R. Müßig, F. Becker, F. K. Harung, H. Schöneseiffen, C. Kukwa (2011), “Concepts, Challenges and Market Potential for Online Food Retailing in Germany", Working Paper, Department of Business Policy and Logistics, University of Cologne, 108. 
Foley Retail Consulting, Can Online Grocery Retailing be Profitable? https://www.foleyretailconsulting.com/canonline-grocery-retailing-be-profitable/, E.T.: 25.11.2020.

Gladman, R. (2021), Pandemic year brings about huge growth for online grocery, https://ahdb.org.uk/news/consumer-insight-pandemic-year-brings-about-huge-growth-for-onlinegrocery, E.T.: 12.10.2021.

Grant, D. B., J. Fernie, B. Schulz (2014), "Enablers and Barriers in German Online Food Retailing”, Supply Chain Forum: An International Journal, 15(3), 4-11, Chttps://doi.org/10.1080/16258312.2014.11517346.

Grewal, D., R. Krishnan, M. Levy, J. Munger (2010), Retail Success and Key Drivers, in Retailing in the 21st Century, Springer, 15-30, Berlin, Heidelberg.

Gustafsson, J. (2017), Single case Studies vs. Multiple Case Studies: A Comparative Study, Halmstad, Sweden: Halmstad University.

Gürman, A. (2006), "Dünya Perakdeciliğinde Globalleşme ve Türk Perakendecilik Sektörüne Etkiler”, Yüksek Lisans Tezi, Dokuz Eylül Üniversitesi, Sosyal Bilimler Enstitüsü, İzmir.

Güven, H. (2020), "Covid-19 Pandemik Krizi Sürecinde E-ticarette Meydana Gelen Değişimler”, Avrasya Sosyal ve Ekonomi Araştırmaları Dergisi, 7(5), 251-268.

Habertürk (2020), Migros, Online Satış Kapasitesini Artırmak için Gölge Mağazalarını Devreye Aldı. https://www.haberturk.com/migros-golge-magazalarini-devreye-aldi-2662854-ekonomi, E.T.: 8.12.2020.

Hacıalioğlu, A. B., M. Sağlam (2021), "Covid-19 Pandemi Sürecinde Tüketici Davranışları ve E-Ticaretteki Değişimler”, Medya ve Kültürel Çalışmalar Dergisi, Cilt 3, Sayı 1, 16-29.

Hafiz, K. (2008), Case Study Ecmple, The Qualitative Report, 13(4), 544-559.

Hatipoğlu, A. (2021), Covid-19 Pandemisinin Küresel Gıda Tedarik Zincirine Etkileri, İktisadi Teori ve Gelişmelere Gelenekçi ve Yenilikçi Yaklaşimlar, Gazi Kitabevi, 335-261.

Hisano, A. (2020), How Sight-Not Taste, Smell, or Touch-Became the Sense of the Supermarket. https://behavioralscientist.org/how-sight-not-taste-smell-or-touch-became-the-sense-of-thesupermarket/, E.T.: 20.11.2021.

Hobbs, J. E. (2020), "Food Supply Chains During the COVID-19 Pandemic", Canadian Journal of Agricultural Economics/Revue Canadienne d'agroeconomie, 68 (2), 171-176.

Hübner, A. H., H. Kuhn, M. G. Sternbeck (2013), Demand and Supply Chain Planning in Grocery Retail: An Operations Planning Framework, International Journal of Retail \& Distribution Management, 41 (7), 512-530.

Hübner, A., A. Holzapfel, H. Kuhn (2016a), “Distribution Systems in Omni-Channel Retailing”, Business Research, 9(2), 255-296.

Hübner, A. H., H. Kuhn, J. Wollenburg (2016b), Last Mile Fulfilment and Distribution in Omni-Channel Grocery Retailing: A Strategic Planning Framework, International Journal of Retail \& Distribution Management, 44(3), $228-247$.

International Labor Organization (2020), "ILO Monitor 2nd edition: COVID-19 and the World of Work Updated Estimates and Analysis", In International Labour Organization, https://doi.org/10.18356/ba5cc386-en, E.T.: 25.12.2020.

İri, R. (2021), Covid-19 Pandemi Sürecinin Niğde ve Yöresindeki Tüketicilerin İnternet Üzerinden Satın Alma Davranışlarına Etkisi, Adıyaman Üniversitesi Sosyal Bilimler Enstitüsü Dergisi, (37), 570-602.

Jha, R. (2019), Online Shopping: Impact on City Planning and Infrastructure, (ORF) Observer Research Foundation, https://www.orfonline.org/expert-speak/online-shopping-impact-city-planning-infrastructure-46937/, E.T.: 20.02.2021.

Jones, K. (2020), How COVID-19 Consumer Spending is Impacting Industries, Visual Capitalist, https://www.visualcapitalist.com/consumer-spending-impacting-industries/, E.T.: 30.04.2020.

Kashyap, N. (2021), Online Grocery Shopping in India: Anticipating Trends Post-Pandemic. European Journal of Molecular \& Clinical Medicine, 07(10), 3664-3672. 
Kämäräinen, V., M. Punakivi (2002), "Developing Cost-Effective Operations for the E-grocery Supply Chain", International Journal of Logistics, 5(3), 285-298.

Klepek, M., R. Bauerová (2020), "Why do Retail Customers Hesitate for Shopping Grocery Online? Technological and Economic Development of Economy", 26(6), 1444-1462.

Kocaman, E. M., M. Kocaman, G. Teyin (2021), “Covid-19 Salgını Döneminde Yiyecek İçecek Sektöründe E-Ticaret Uygulamaları ve Bir Model Önermesi", Journal of Tourism and Gastronomy Studies, 9(2), 1286-1301.

KPMG (2021), "The Future of Retailing", https://assets.kpmg/content/dam/kpmg/au/pdf/2021/future-of-retail2021-report.pdf, E.T.: 02.02.2021

Lang, G. (2010), “Multi-Channel Retail Supply Chain Management: Fulfillment systems in Multi-Channel RetailingCustomer Expectations and Economic Performance", 8th International Research Conference in Logistics and Supply Chain Management, 1-25.

Li, J., A.G. Hallsworth, J.A. Coca-Stefaniak (2020), "The Changing Grocery Shopping Behavior Among Chinese Consumers at the Outset of the COVID-19 Outbreak", Tijdschrift voor Economische en Sociale Geografie, Vol.111, Issue 3, 574-583. https://doi.org/10.1111/tesg.12420.

Maptriks (2020), İstanbul Perakende Sektörü Veri Tabanı, https://maptriks.com/tr/sektorler/perakende-toptanticaret/, E.T.: 02.05.2020.

Martin-Neuninger, R., M. B. Ruby (2020), "What Does Food Retail Research Tell Us About the Implications of Coronavirus (COVID-19) for Grocery Purchasing Habits?", Frontiers in Psychology, Vol. 11, Article 1448.

McKinsey \& Company (2020a), How COVID-19 has pushed companies over the technology tipping point-and transformed business forever, https://www.mckinsey.com/business-functions/strategy-and-corporate finance/our-insights/how-covid-19-has-pushed-companies-over-the technology-tipping-point-andtransformed-business-forever, E.T.: 25.12.2020.

McKinsey \& Company (2020b), "Future of Retail Operations: Winning in a digital era", https://www.mckinsey.com/, E.T.: 08.11.2020.

Mellahi, K., M. Johnson (2000), "Does it Pay to be a First Mover in E.commerce? The case of Amazon.com", Management Decision, 38 (7), 445-452.

Mercatus (2020), eGrocery's New Reality: The Pandemic's Lasting Impact on U.S. Grocery Shopping Behavior, https://info.mercatus.com/,E.T.: 25.12.2020.

Mintel (2021), Click \& Spend: 90\% of British Online Grocery Shoppers Plan to Continue Online Grocery Shopping After Peak Covid-19 Passes, https://www.mintel.com/press-centre/food-and-drink/click-spend-90-of-brits-planto-continue-online-grocery-shopping-even-after-peak-covid-19-passes, E.T.: 11.10.2021.

Moriset, B. (2020), The Geography of e-Commerce, Barney Warf (Ed.), Geographies of the Internet, London, Routledge, 139-156.

Murphy, A. J. (2003), (Re) Solving Space and Time: Fulfilment issues in online grocery retailing. Environment and planning A, 35(7), 1173-1200.

National Retail Fedaration, “Top 50 Global Retailers 2020”, https://nrf.com/resources/top-retailers/top-50-globalretailers/top-50-global-retailers-2020, E.T.: 21.1.2020.

Nielsen (2015), The future of grocery e-commerce, digital technology and changing shopping preferences around the World, https://www.nielsen.com/wp-content/uploads/sites/3/2019/04/nielsen-global-e-commerce-newretail-report-april-2015.pdf, E.T.: 16.12.2020.

Önemli, S. (2020), Online Market Alş̧verişlerine Koronavirüs Etkisi, Digitalage, https://digitalage.com.tr/online-market-alisverislerine-koronavirus-etkisi/, E.T.: 01.05.2020.

Popov, A. (2021), How COVID-19 Triggered The Digital and E-commerce Turning Point, https://unctad.org/news/how-covid-19-triggered-digital-and-e-commerce-turning-point, E.T.:25.09. 2021.

Pucci, R. (2021), Online Grocery Sales To Continue Record Pace Post-Pandemi. https://www.paymentsjournal.com/online-grocery-sales-to-continue-record-pace-post-pandemic/, E.T.: 12.11. 2021. 
Raguneethan, R. (2021), How Shifting Consumer Habits are Revealing the Future for Retail, https://news.microsoft.com/apac/2021/06/04/how-shifting-consumer-habits-are-revealing-the-future for-retail/, E.T.: 12.11. 2021.

Saunders, N. (2018), Online Grocery: Lessons from History, One Space. https://www.onespace.com/blog/2018/10/online-grocery-lessons-history/, E.T.: 20.11.2020.

Sheth, J. (2020), "Impact of Covid-19 on Consumer Behavior: Will the Old Habits Return or Die?", Journal of Business Research, 117, 280-283.

Sosyal Güvenlik Kurumu (SGK) (2018), İşyeri ve Sigortalılara Ait İstatistikler, Ankara, Türkiye.

Stephany, F., N. Stoehr, P. Darius, L. Neuhäuser, O. Teutloff, F. Braesemann (2020), “The CoRisk-Index: A Data-Mining Approach to Identify Industry-Specific Risk Assessments Related to COVID-19 in Real-Time”, Working paper, 1-20.

Şen, M. A. (2020)," Koronavirüs (Covid-19) Salgınının Türkiye'deki Yemek Firmalarında Oluşturduğu Etkinin Belirlenmesi Üzerine Bir Araştırma", Afet ve Risk Dergisi, 3(1), 89-100.

T.C. İçişleri Bakanlığı (2020), 65 Yaş ve Üstü ile Kronik Rahatsızlı̆̆ı Olanlara Sokağa Çıkma Yasağı Genelgesi. https://www.icisleri.gov.tr/65-yas-ve-ustu-ile-kronik-rahatsizligi-olanlara-sokaga-cikma-yasagi-genelgesi, E.T.: 02.05. 2020.

T.C. İçişleri Bakanlığı (2020), Koronavirüs Tedbirleri Genelgesi Kapsamında 149.382 iş Yeri Geçici Süreliğine Faaliyetlerine Ara Verdi, https://www.icisleri.gov.tr/koronavirus-tedbirleri-genelgesi-kapsaminda-149382is-yeri-gecici-sureligine-faaliyetlerine-ara-verdi, E.T.: 16.06.2020.

Teodoro, A. (2020), Coronavirus: Food Supply Chains Under Threat from Lockdown Measures, MDS Transmodal.

https://www.mdst.co.uk/coronavirus-food-supply-chains-under-threat-from-lockdown-measures, E.T.: 28.04.2020.

The Daily Telegraph (2009), Tesco to Open Customer-free 'Dark Stores'. https://www.telegraph.co.uk/finance/newsbysector/epic/tsco/6743329/Tesco-to-open-customer-freedark-stores.html, E.T.: 27.11.2020.

Thompson, D. (2017), Why Amazon Bought Whole Foods, The Atlantic. https://www.theatlantic.com/business/archive/2017/06/why-amazon-bought-whole-foods/530652/, E.T.: 25.12.2020.

Türkiye İstatistik Kurumu (TÜiK) (2018), Bölgesel İstatistikler, Ankara, Türkiye.

Türkiye İstatistik Kurumu (TÜiK) (2019), Adrese Dayalı Nüfus Kayıt Sistemi Sonuçları, Ankara, Türkiye.

Türkiye Perakendeciler Federasyonu (TPF), Sektör Bilgileri, https://www.tpf.com.tr/sektorel-bilgiler/, E.T.: 24.04.2020.

United Nations Conference on Trade and Development (Unctad) (2020), COVID-19 has changed online shopping forever, survey shows, https://unctad.org/news/covid-19-has-changed-online-shopping-forever-surveyshows, E.T.: 28.11. 2020.

USDA (2021), COVID-19 Accelerates the Growth of India's Online Grocery Market, United States Department of Agriculture and Global Agricultural Information Network, Voluntary Report, IN2021-0067, https://apps.fas.usda.gov/, E.T: 20.11.2020.

Verhoef, P. C., P. K. Kannan, J. J. Inman (2015), “From Multi-Channel Retailing to Omni-Channel Retailing”, Journal of Retailing, 91(2), 174-181.

Wang, Y., R. Xu, M. Schwartz, D. Ghosh, X. Chen (2020), “COVID-19 and Retail Grocery Management: Insights from a Broad-Based Consumer Survey", IEEE Engineering Management Review, 48(3), 202-211.

Wyman, O. (2018), "Retail's Revolution: How the Retail and Consumer Goods Companies Can Adapt". Marsh\&Mclennan Companies, https://www.oliverwyman.com/, E.T: 28.11.2020.

Yin, R. K. (2003), Case Study Research: Design and Methods, Applied Social Research Methods Series, Thousand Oaks, CA: Sage. 